DOI: $10.2478 /$ rpp-2014-0015

Doctor of Pedagogical Sciences, full professor, VIRA POLISHCHUK Ternopil V. Hnatiuk National Pedagogical University Address: 2 Kryvonosa Str., Ternopil, 46000, Ukraine E-mail: pol_vira@mail.ru

$\mathrm{PhD}$ (pedagogical sciences), HANNA SLOZANSKA Ternopil V. Hnatiuk National Pedagogical University Address: 2 Kryvonosa Str., Ternopil, 46000, Ukraine E-mail:kulynyak@rambler.ru

\title{
INNOVATIVE APPROACH TO THE ORGANIZATION OF FUTURE SOCIAL WORKERS' PRACTICAL TRAINING: FOREIGN EXPERIECE
}

\begin{abstract}
Innovative approaches to practical training of future social workers in higher educational establishments have been defined. Peculiarities of foreign experience of social workers' practical training in higher educational establishments have been analyzed. Experience of organizing practice for bachelor students studying at "Social Work" specialty in Ternopil National Pedagogical University, namely the aim, tasks, general principles of forming a system of continuous practical training of future social workers, has been studied. Peculiarities of social workers' practical training in the process of undergoing some definite kinds of practices have been analyzed.

Features of cooperation of educational establishments and social services, agencies, institutions, which are the bases for professional training of future specialists, have been defined. The core principle of such cooperation is the principle of regular studying that presupposes combination of theoretical education and real practical activity.

It has been determined that in the process of practical training students deepen and expand their knowledge, are taught to think critically, elaborate and fulfill algorithms of solving different social problems, find information about resources of social help and support as well as their providers, follow ethical principles of social work, estimate results of social intrusion and personal knowledge and skills, improve them.

Key words: social worker, professional training, continuous practical training, bachelor qualification level, education and vocational training program

\section{INTRODUCTION}

Active modernization of society that is accompanied by an acceleration of sociocultural development, complexity of the living environment of people, political dynamics, changes in human values and preferences update the need to develop social work as a professional activity and direction of vocational training. Social policy is one of the most important activities of the state and social work aim is to create favourable living conditions and life realization of citizens, practical solutions to social problems, providing assistance to vulnerable members of society. This activity is aimed not only and not so much at improving the material well-being of the poor, that is charity, but, above all, at the expansion of the sphere of social interaction between people, their adaptation to the realities of life, engagement in active, full role in society.

The social worker is a professional specialist, presupposed to solve social problems in various sectors of citizens' life, regardless of their age, gender, social status. An important area of
\end{abstract}


social workers' professional activity is to help individuals or groups of individuals who find themselves in difficult situations in order to improve or restore their capacity for social functioning.

Modern conditions of social, economic, political, ideological development of Ukraine need the development and implementation of a new concept of future social workers' training in higher education establishments that would facilitate the integration of scientific knowledge, raising the level of professionalism, competence, intellectual culture of specialists. Tasks designated by National Doctrine of Education Development include directing higher education to provide basic science, general cultural and practical components of the social sphere specialists' training. The actualization of the last part, we believe, will improve the integrated system of future social workers' training in Ukraine, that will make them able to work in complex socio-political and economic conditions of today.

\section{THE AIM OF THE STUDY}

The aim of the study is to analyze the innovative approaches to practical training of future social workers in higher educational establishments.

\section{THEORETICAL FRAMEWORK AND RESEARCH METHODS}

The professional training of social workers is the subject of research conducted by many domestic and foreign scholars. In modern domestic science series of studies reveal different aspects of future social workers' training. In particular, the content and the main areas of social/socio-educational activities are revealed in the works of A. Bezpalko, A. Capska, N. Chernuha, M. Husak, S. Kharchenko, I. Kozubovskyi, G. Laktionova, M. Lukashevich, I. Migovich, J. Petrochko, Y. Polishchuk, L. Romanovska, A. Ryzhanova, S. Savchenko, L. Stephan, I. Zverev etc.; the process of professional training of social workers is described in the works of A. Homonyuk, T. Logvynenko, L. Mischyk, R. Vaynola etc.; the peculiarities of their training aimed at work in different areas of social activity and with different groups of clients are revealed in researches of J. Kichuk, J. Kovchyna, N. Oleksyuk and others.

Foreign experience of social workers' training is revealed in the works of domestic scientists. Professional training of social workers in Australia is described by G. Slozanska, in Austria - by A. Pavlishak, in Great Britain - by V. Kozubovskyy, A. Pichkar, in Canada - by N. Haiduk, H. Mykytenko, A. Olkhovich, in Poland - by S. Kohut, in Germany - by O. Pryshlyak, in the USA - by N. Sobchak, V. Tymenko, L. Vinnikova, in France - by G. Leshchuk, in Sweden - by A. Ball and others.

Foreign scientists that analyze social workers' training are B. Dick, R. Dixon, L. Hadzhes, K. Kennedy, J. Lawrence, E. Martin (Australia), G. Vilfinh (Austria), R. Massana, D. Remion (Belgium), G. Serenzen (Denmark), M. Dowell, C. Ramon, T. Shanin, P. Shardlou (UK), A. Fisher, D. Hoffman (Germany), V. Bocharov, L.Halahuzova, A. Panov, P. Pavlenok, T. Yarkin (Russia), J. Cross, V. Griffith, A. Sprinkled (USA), P. Bashler, B. Buquet, F. Laot, S. Luatron, E. Zhovelen, (France), I. Valliman (Switzerland) and others.

\section{RESULTS}

The analysis of the theory and practice of foreign and domestic experience of social workers' professional training shows close interaction of educational institutions and social service agencies, institutions that are bases for the exercise of professional training of future professionals. The basis of such cooperation is training that involves a combination of theoretical education and actual practice in order to create optimal conditions in which students have the ability to absorb knowledge, acquire skills and abilities by applying them to specific practical situations.

This approach requires students' social skills of projecting, organization of teamwork, intensive individual work and individual approach to each student, and most importantly, 
effective interaction and coordination of institutions, students and their practical training bases (Слозанська, 2011).

During practice students deepen their knowledge and skills, forms of behavior in real professional situations, willingness to solve certain problem situations, determine which kind of practice they like more, if they have the motivation to implement practical social work.

The aim of future social workers' practical training in foreign countries (Australia, UK, Canada, Germany, USA, France) is the integration of theoretical knowledge and practical skills necessary to successfully address the professional activity of social workers; obtaining of initial practical experience by future professionals; providing them with various techniques of social work and shaping ability to choose and apply the most effective ones for a particular situation; learning of social work ethics; use of supervision to analyze their own feelings, generated values and personal aspects, social projects; conducting research to better serve different types of customers and assess the level of readiness to professional activity (Лещук, 2008; Пічкар, 2002; Поліщук, 2006; Слозанська, 2011; Собчак, 2004).

The basic principles underlying the practical training of future social workers in foreign higher education institutions are: the optimal combination of theoretical and practical training, subordination to the urgent task of social work practice, encouraging students to selfselection of places to practice, organization of practice on a social worker's workplace, the active involvement of students during practice to the challenges of professional activity; selection of curators among professionals who have practical experience in social service.

A characteristic feature of international experience of social workers' training is that the basis of practice is not only a place of students' practical training, but usually the place of future employment.

The analysis shows that the length, content, forms and methods of practical training, accounting documentation are specified by educational establishments and are mentioned in the requirements for student internships and practical training programs. The program of future specialists' practical training is typically developed by higher educational establishment together with social institutions or agencies. A typical program of practical training reveals the purpose, objectives, outcome, forms and methods of its conducting and procedures for student assessment. It corresponds to the mission of the institution, aim of the professional training, reflects the concept of practical training and the needs of the community. One requirement that relates to the application of field practice is taking into account the specific social institution on the basis of which students will have practice (orphanages, shelters, rehabilitation centers, social agencies etc.) and categories of customers with whom institutions operate (elderly people, people with special needs or disabilities, and others) (Слозанська, 2012).

Let's note that in each country there is their traditional correlation between theoretical and practical part of future social workers' training, the most common is the ratio of $40 \%$ to $60 \%$ (Australia, UK, Canada, USA, France). Typical is the fact that each institution determines the period of students' practice, its tasks, semester distribution of hours and determines the number of allocated credits.

The organization and provision of the necessary conditions for practical training and resources are provided by field instructors, coordinators and supervisors of practice tasks / integrative seminar teachers (Australia, Canada, USA), teachers and mentors (UK), the head assistant practice managers (France) and others.

In the literature there are three main approaches to the practical training of future social workers: mentoring, integrative and combinative practice (Поліщук, 2006). We consider it necessary to reveal the features of these approaches. The essence of mentoring approach is the observation of students at work by experienced specialist in social services. It is based 
on the use of inductive method in teaching (combination of theoretical knowledge and practice) and requires from the school the organization of students' practice from almost the first day of classes in a large volume of time. This approach provides a limited impact of teaching staff on the process of hands-on training. Role of the institution that is responsible for liaison with social services is to analyze the results of students only with the aim of controlling their overall development in the context of training. The primary responsibility for linking academic and practical learning processes is assigned to students and teachers of practice. Therefore tutorial approach in its pure form is used infrequently.

The academic approach focuses on developing students' knowledge; practical classes are considered to be examples of the learning process. According to this approach, the principal value of an educated person is the knowledge with practical application. The academic approach is dominant in many applications to get a college degree. For these programs, the practice is usually held in the last semester of the academic course of students' study.

Combinative approach is characterized by an organic relationship of academic learning process and the learning process during practice. It requires shared responsibility of teaching staff, teachers and students for the impact of the training process. The process of mastering knowledge, its understanding and practical application has an equivalent value. Reliance on combinative approach assumes that in the process of future social workers' training the emphasis is not only on the mastery of theoretical knowledge but also on practical skills regarding social services, meaningful understanding of the causes of phenomena and selection of optimal influence technologies. This approach enables students to master the art of personal work style.

Generalized analysis of foreign experience of social workers' practical training indicates a high degree of unity of practical and theoretical training of future professionals, the existence of regulatory guidance documents and variability of practice models.

We are far from thinking about the feasibility and necessity of blind copying of international experience in practical training of future social sphere professionals into the educational environment of Ukraine. However, some progressive ideas of this experience deserve more detailed study and implementation.

Practical training of students majoring in "Social Work" specialty at V. Hnatiuk Ternopil National Pedagogical University is based on its continuity, integrated approach to the definition of objectives, content, forms and methods of organizing and conducting, ensuring continuity and consistency in the various stages of its implementation.

The objective of practical training is to deepen and broaden the theoretical knowledge of students gaining professional competence, form their vocational skills, personal qualities and readiness to professional activities.

Practical training of future social workers is carried out according to the educational and vocational training programs. Terms of practical training depend on their type and curriculum. Goals, objectives, content, structure, reporting forms, diagnostic tools and evaluation criteria are defined by programs of each type of practice that are worked out by chairs teachers, social service agencies and approved by the Academic Council of the University.

Schedule of practical training of bachelor degree students of the specialty "Social Work" is given in Table. 1 .

Practical training of future social workers studying for bachelor degree (years I-IV) take place in social institutions which entered into cooperation agreements with places of permanent or temporary employment of students, contributing to their future employment.

Assistance in organizing the necessary conditions and resources for practical training is provided by practice managers, facilitators (teachers of higher educational institutions) 
and methodologists (employees from bases of training). The coordination of each type of practice is carried out by practice leader, who works with the staff of social services institutions (schools).

Table 1

Schedule of practical training of bachelor degree students

of the specialty "Social Work" in V. Hnatiuk Ternopil National Pedagogical University

\begin{tabular}{|c|c|c|c|c|}
\hline Type of practice & Course & Semester & Credits & Type of final control \\
\hline Trial practice & 1 & 1 & 2 & test \\
\hline Charitable practice & 2 & 4 & 2 & test \\
\hline Organizational recreation practice & 2 & 4 & 2 & test \\
\hline Teaching practice & 3 & 5 & 3 & test \\
\hline Practical training & 4 & 7 & 4 & test \\
\hline Qualifying practice & 4 & 8 & 6 & differentiated test \\
\hline
\end{tabular}

Methodologists of practice from a higher education establishment that provide the relationship between higher education institutions, students and databases of practice are responsible for the results of practical training. Together with the methodologists from the bases of practice they work at the integration of theoretical knowledge and practical skills of students and meet the challenges of practice implementation.

Choosing a future place to practice, the distribution of students, assignment of trainers, formulation of purpose, objectives of a particular type of practice is the task of a practice leader. His duties also include the organization of a seminar at which the heads of practice together with the workers of social institutions explain to students the organizational aspects of practical training program and the logic of its organization and implementation, peculiarities of social services activities, which are the bases of practice, tell about clients they work with, a system of diagnostics and evaluation. At the end of the seminar students fill in an integrative personal information form, which indicates personal data, information about their previous practice, (volunteer) work experience, academic year, expectations, wishes and needs that they would like to meet during the internship, and the scope of its practical interest.

Taking into account the wishes of students indicated in a personal information form, the head of the practice establishes cooperation with social services and gives the students detailed information about the place of practice. With the proposed database of practice, students choose one or two, pointing them in the application for an internship. The final decision about where the practice takes place is made by a practice leader, who discusses specific details of its organization with social service and gives the student direction or permission to practice in a particular institution.

The relationship between universities and practice are based on mutual agreement, which defines the duties and responsibilities of each party and the conditions under which services are provided. Before the practice a manager of practice conducts preliminary prescriptive instruction, which involves students, methodologists from institution of higher education and bases of practice. The purpose of this briefing is to bring to the attention of the participants goals, objectives of practical training and necessary theoretical knowledge and practical skills to achieve them; planned types of tasks and methods of their realization, analysis types, forms and methods of the students' activities during practice, reporting forms, evaluation criteria.

All practices are completed with a final conference where the head of the practice, methodologists and representatives of social services and the students summarize practical training and evaluate the work of students. 
The results of the practice of bachelor degree students studying at "Social work" specialty are evaluated according to the requirements of credit-modular system of training on a 100-point scale with the note "Passed" or "Unapplied". Qualifying practice is assessed by a differentiated credit. A complex grade, received by a student during an internship, is calculated with the account of the following criteria: the extent to which a student has fulfilled the assignments of the practice, the quality and timeliness of the performance, professional behavior of students, the comments and recommendations of the chief and the methodologist of practices, atendance, activeness and timeliness of performing the tasks of the prescriptive instruction and workshop.

Students, who have not passed the practice because of valid reasons, are entitled to its continuation in their free time. Students, who have not passed the practice without a valid reason or received a failing grade, can not be allowed to take the state exam in the specialty. By decision of a dean a student may be recommended for expulsion from the university.

\section{CONCLUSIONS}

Social education in Ukraine is faced with a difficult task of balancing the difficult situation today, putting the focus on a person, whose security, standards of living, rights and well-being should be improved considerably. Solution of this problem requires the whole experience and knowledge accumulated in our country and we must learn to use them wisely and develop them in the context of international standards.

Materials of our study allow us to conclude that the creative use of progressive ideas of international experience concerning practical training of future social workers contributes to the improvement of this process at V. Hnatiuk Ternopil National Pedagogical University.

Students in the process of practical training deep and expand their knowledge, learn how to think critically, develop and implement algorithms for solving various social problems, find information about social care and support resources as well as their providers, ethically observe the principles of social work, assess the performance of social intervention and personal skills, work on their improvement.

\section{REFERENCES}

1. Лещук, Г. В. (2008). Система професійної підготовки фахівизів соиіальної сфери у Франиії [System of professional training of social sphere specialists in France]. Doctoral thesis. Тернопіль: ТНПУ ім. В. Гнатюка, 240 р. (in Ukrainian).

2. Пічкар, О.П. (2002). Система підготовки фахівияів соціальної роботи у Великій Британії [System of social work specialists' training in Great Britain]. Doctoral thesis. Ужгород, 213 p. (in Ukrainian).

3. Поліщук, В. А. (2006). Теорія і методика підготовки соціальних педагогів в умовах неперервної освіти [Theory and methodology of training social pedagogues under conditions of life-long education]. Doctoral thesis. Тернопіль: ТНПУ ім. В. Гнатюка, 454 р. (in Ukrainian).

4. Слозанська, Г. I. (2012). Практична підготовка студентів спеціальності «Соиіальна робота»: методичний посібник [Practical training of "Social Work" speciality students: handbook]. Тернопіль: ТНПУ ім. В. Гнатюка, 190 p. (in Ukrainian).

5. Слозанська, Г. І. (2011). Професійна підготовка соціальних працівників у вищих навчальних закладах Австралії [Professional training of social workers at higher educational establishments of Australia]. Doctoral thesis. Тернопіль: ТНПУ ім. В. Гнатюка, 229 р. (in Ukrainian).

6. Собчак, Н. М. (2004). Зміст і форми професійної підготовки соизільних працівників у системі неперервної освіти США [Content and forms of social workers' professional training in system of continuous education of the USA]. Doctoral thesis. Тернопіль: ТНПУ ім. В. Гнатюка, 181 р. (in Ukrainian). 